\title{
Environmental drivers of fish community functional diversity in arid mangroves compared to a tropical estuary
}

\section{Factores ambientales determinantes de la diversidad funcional de la comunidad de peces en manglares áridos en comparación con un estuario tropical}

\author{
Juan Ángel Payan-Alcacio, Gustavo De La Cruz-Agüero, Rodrigo Moncayo-Estrada* \\ Instituto Politécnico Nacional-Centro Interdisciplinario de Ciencias Marinas, Avenida Instituto Politécnico \\ Nacional, S/N, 23096, La Paz, Baja California Sur, Mexico. \\ * Corresponding author. E-mail: rmoncayo@ipn.mx
}

\begin{abstract}
Mangroves are important habitats for fish across latitudinal gradients, but few studies have examined fish community functional diversity in mangroves from arid environments. To address this, we assembled 11 morpho-functional traits and taxonomic diversity for 123 fish species and environmental characteristics from 3 mangrove ecosystems in the Gulf of California, where arid conditions prevail. We compared these arid mangrove fish communities to a semitropical community in an estuarine condition to analyze functionality. Arid mangrove fish communities were similar to each other, but different from semitropical estuarine fish communities $(R=0.951, P=0.007)$. Mangrove fish communities had higher trait diversity than the estuarine community, but the estuary had higher redundancy. Taxonomic diversity showed a latitudinal gradient, with the southernmost site in the arid region functioning as a transition site to estuarine communities. Despite the different taxonomic composition, the functional structure remained similar in the fish communities within the arid region and had higher counts of diverse traits than the site with estuarine conditions. High salinity and evaporation deficit in the arid mangroves relaxed habitat filtering pressures relative to the estuarine conditions, where the higher tolerance to salinity changes imposes redundant morphologies. Future studies should focus on seasonal variation of environmental effects on the functional aspects of the fish community.
\end{abstract}

Key words: richness, dispersion, redundancy, taxonomic diversity, Gulf of California.

RESUMEN. Los manglares son hábitats importantes para los peces a través de los gradientes latitudinales, pero pocos estudios han examinado la diversidad funcional de las comunidades de peces en ambientes áridos. Para abordar esto, reunimos 11 atributos morfofuncionales y analizamos la diversidad taxonómica de 123 especies de peces, además de analizar las características ambientales de 3 ecosistemas de manglar en el golfo de California, donde prevalecen condiciones áridas. Comparamos estas comunidades de peces de manglar árido con una comunidad semitropical en condiciones estuarinas para analizar la funcionalidad. Las comunidades de peces de los manglares áridos fueron similares entre sí, pero diferentes de las comunidades de estuarios semitropicales $(R=0.951, P=0.007)$. Las comunidades de peces de los manglares áridos tuvieron una mayor diversidad de atributos que la comunidad estuarina, pero esta presentó una mayor redundancia de atributos. La diversidad taxonómica mostró un gradiente latitudinal, donde el sitio más sureño de la región árida funcionó como un sitio de transición para las comunidades estuarinas. A pesar de la diferente composición taxonómica, la estructura funcional siguió siendo similar en las comunidades de peces dentro de la región árida y obtuvo un mayor número de diversos atributos que el sitio en condiciones estuarinas. El alto déficit de salinidad y evaporación en los manglares áridos redujo la presión de filtrado del hábitat en relación con las condiciones estuarinas, donde la mayor tolerancia a los cambios de salinidad impone morfologías redundantes. Los estudios futuros deberán centrarse en la variación estacional de los efectos ambientales en los aspectos funcionales de la comunidad de peces.

Palabras clave: riqueza, dispersión, redundancia, diversidad taxonómica, golfo de California.

\section{INTRODUCTION}

Mangroves are important coastal environments around the circumtropical belt characterized by low-energy intertidal habitats (Sheaves 2017). Mangrove forest biodiversity and structure provide several ecological services, including ecosystem processes such as carbon sequestration, shore protection barriers (Barbier et al. 2011), and economically important fishing grounds (Costanza et al. 1997). Given the perceived beneficial effects of mangroves, their conservation is considered as a key issue in coastal environments (Al-Maslamani et al. 2013). In terms of associated fishes,

\section{INTRODUCCIÓN}

Los manglares son importantes ambientes costeros alrededor del cinturón circumtropical que se caracterizan por presentar hábitats intermareales de baja energía (Sheaves 2017). La estructura y la biodiversidad de manglares brindan varios servicios ecológicos, incluidos procesos del ecosistema como el secuestro de carbono, barreras de protección costera (Barbier et al. 2011) y zonas pesqueras económicamente importantes (Costanza et al. 1997). Debido a los beneficios que presentan los manglares, su conservación se considera un tema clave en el entorno costero (Al-Maslamani 
mangroves are breeding, nursery, and feeding grounds for juvenile and transitive species (Lugendo et al. 2007).

Although during the past 3 decades there has been an increase in the number of studies related to the fish communities in mangrove habitats, most of the publications are geographically biased to certain continents and countries and are consequently related more to tropical environmental conditions (Faunce and Serafy 2006). As a result, there is a lack of information regarding other climates, such as the arid type in the northernmost geographical distribution.

The northern Pacific coast of Mexico has a predominantly arid and semiarid climate. Along the Gulf of California (GC), there are several mangrove patches in bays and protected coastal zones in the states of Baja California Sur, Sonora, and Sinaloa (Payan-Alejo 2012). Coverage of these mangrove habitats has not changed significantly, but Sinaloa has experienced coverage loss due to anthropogenic pressures (CONABIO 2009). The region presents brief seasonal rainfall mainly related to the influence of hurricanes and tropical storms.

In general, the mangrove habitat in this region is relatively undeveloped, usually limited to a narrow fringe bordering the coast discontinuously (Millán-Aguilar et al. 2020). It grows under suboptimal conditions such as tidal saltwater with higher salinity values than tropical areas (López-Medellín and Ezcurra 2012), resulting in relatively lower habitat complexity and lower fish species richness (Ochoa-Gómez et al. 2018). In this context, the present study includes the analysis of the fish community within the arid mangrove type near its distribution limit in the American Pacific and compares it to a site with estuarine conditions as a reference point.

The number of studies on the biogeography and composition of mangrove fishes in the region has begun to increase (Padilla-Serrato et al. 2017) to understand how the carbon input affects the food webs (Ochoa-Gómez et al. 2018) and how environmental conditions affect the diversity and distribution of these fish communities (Padilla-Serrato et al. 2016). Although these studies are important to understand the organization and complexity of communities in select areas of the GC, complementary analyses must also be implemented to identify intra and interspecific relationships and the regional structure and dynamics of the communities.

There are 3 different ecological approaches to explore the structure of fish communities in a multifaceted way: the classical approach, which considers ecological indices related to abundance and species richness; the taxonomic approach, which considers phylogenetic relationships of species revealing similarities in the evolutionary pathway (Clarke and Warwick 1999); and the functional approach, which is based on how species perform according to their ecological traits (e.g., feeding strategies, locomotion capabilities, reproduction, behavior, morphological or life history variables; Mason et al. 2005). Particularly, in the context of the functional structure, we have described complementary indices related to the target community. Furthermore, some studies et al. 2013). En términos de peces asociados, los manglares son zonas de reproducción, crianza y alimentación de especies juveniles y transeúntes (Lugendo et al. 2007).

Aunque durante las últimas 3 décadas ha habido un aumento en el número de estudios relacionados con las comunidades de peces en hábitats de manglar, la mayoría de las publicaciones están sesgadas geográficamente a ciertos continentes y países, y en consecuencia están más relacionadas con las condiciones ambientales tropicales (Faunce y Serafy 2006). Como resultado, existe la falta de información sobre otros climas, como el tipo árido en su distribución geográfica más septentrional.

La costa del Pacífico norte de México tiene un clima predominantemente árido y semiárido. A lo largo del golfo de California (GC), hay varios parches de manglar en bahías y zonas costeras protegidas en los estados de Baja California Sur, Sonora y Sinaloa (Payan-Alejo 2012). La cobertura de estos hábitats de manglar no ha cambiado significativamente, a excepción de Sinaloa, que ha experimentado una pérdida del área debido a la presión antropogénica (CONABIO 2009). La región presenta lluvias estacionales ocasionales relacionadas, principalmente, con la influencia de huracanes $\mathrm{y}$ tormentas tropicales.

En general, el hábitat de manglar en esta región está relativamente poco desarrollado, limitado a una franja estrecha que bordea la costa de manera discontinua (Millán-Aguilar et al. 2020). Crece en condiciones subóptimas como las de aguas de marea con valores de salinidad más altos que en las zonas tropicales (López-Medellín y Ezcurra 2012), lo que resulta en una menor complejidad del hábitat relativa y una baja riqueza de especies de peces (Ochoa-Gómez et al. 2018). En este contexto, el presente estudio incluye el análisis de la comunidad de peces dentro del tipo de manglar árido cerca de su límite de distribución en la costa americana del Pacífico y lo compara con un sitio con condiciones estuarinas como punto de referencia.

El número de estudios sobre la biogeografía y la composición de los peces de manglar en la región ha empezado a incrementar (Padilla-Serrato et al. 2017) para comprender cómo el aporte de carbono afecta las redes tróficas (OchoaGómez et al. 2018) y cómo las condiciones ambientales afectan la diversidad y la distribución de estas comunidades de peces (Padilla-Serrato et al. 2016). Aunque estos estudios son importantes para comprender la organización y la complejidad de las comunidades en áreas seleccionadas del GC, se deben implementar análisis complementarios para identificar las relaciones intra e interespecíficas, así como la estructura regional y la dinámica de las comunidades.

Existen 3 diferentes enfoques ecológicos para explorar la estructura de las comunidades de peces de una manera multifacética: el enfoque clásico, que considera los índices ecológicos relacionados con la abundancia y la riqueza de especies; el enfoque taxonómico, que considera las relaciones filogenéticas de las especies que revelan similitudes en el proceso evolutivo (Clarke y Warwick 1999); y el enfoque funcional, 
have included more than one of these aspects of fish communities in different ecosystems, suggesting that taxonomic and functional diversity allow to overcome the limitations of the classical perspective, providing insights into the finer ecological processes (Villéger et al. 2010, Zhang et al. 2020).

We addressed 2 hypotheses. (1) The extreme environment drives the functional traits in the assembly process of the fish community structure of the arid mangrove system. Because of this, such traits will be unique to each locality, but the proportion of its functional traits will remain similar at the regional level (northwest Mexico), differing from the estuarine environment. (2) Because of the lack of continuous freshwater input, morphology of the fish community should indicate a higher presence of more specialized species in the arid conditions (sensu Villéger et al. 2010).

\section{MATERIALS AND METHODS}

\section{Study area}

Four sites in the GC northwest region of Mexico were studied. Three of the sites share similar arid environmental conditions, with high evaporation rates $\left(>1,750 \mathrm{~mm} \cdot \mathrm{yr}^{-1}\right)$ that greatly exceed precipitation (López-Medellín and Ezcurra 2012, Table 1). Additionally, they lack permanent freshwater contributions from rivers, and the mangrove trees consequently tend to be dwarfed; the water depth in the coastal mangrove fringe is relatively shallow, with a semimixed tidal regime. The most common mangrove species are Rhizophora mangle, Avicennia germinans, and Laguncularia racemosa (Payan-Alejo 2012, Padilla-Serrato et al. 2016).

Bahía de La Paz (Baja California Sur, BCS) is the largest protected coastal system on the eastern side of the Baja California Peninsula. It is located in the southern region of que se basa en cómo se comportan las especies de acuerdo con sus atributos ecológicos (e.g., estrategias de alimentación, capacidad de locomoción, reproducción, comportamiento, variables morfológicas o de historia de vida; Mason et al. 2005). Particularmente, en el contexto de la estructura funcional, describimos índices complementarios relacionados con la comunidad objetivo. Además, algunos estudios han incluido más de uno de estos aspectos de comunidades de peces en diferentes ecosistemas, con lo cual han determinado que la diversidad taxonómica y funcional permite superar las limitaciones de la perspectiva clásica, lo cual da resolución a los procesos ecológicos más finos (Villéger et al. 2010, Zhang et al. 2020).

Se abordaron 2 hipótesis. (1) El entorno ambiental extremo impulsa los atributos funcionales en el proceso de ensamblaje de la estructura de la comunidad de peces del manglar árido. Debido a eso, dichos atributos serán únicos para cada localidad, pero la proporción de sus atributos funcionales será similar a nivel regional (noroeste de México), difiriendo del ambiente estuarino. (2) Debido a la falta de aporte continuo de agua dulce, la morfología de la comunidad de peces debería indicar una mayor presencia de especies más especializadas en las condiciones áridas (sensu Villéger et al. 2010).

\section{MATERIALES Y MÉTODOS}

\section{Área de estudio}

Se estudiaron 4 sitios en la región del GC en el noroeste de México. Tres de estos sitios compartieron condiciones ambientales áridas similares, con altas tasas de evaporación $\left(>1,750 \mathrm{~mm} \cdot \mathrm{año}^{-1}\right)$ que excedieron ampliamente la tasa de precipitación (López-Medellín y Ezcurra 2012, Tabla 1).

Table 1. Different reported* environmental conditions at the mangrove sites analyzed.

Tabla 1. Diferentes condiciones ambientales reportadas* de los sitios de manglar analizados.

\begin{tabular}{lcccc}
\hline Site & La Paz Bay & $\begin{array}{c}\text { Santa María-La } \\
\text { Reforma }\end{array}$ & Las Guásimas & $\begin{array}{c}\text { Marismas } \\
\text { Nacionales }\end{array}$ \\
\hline Code** & BCS & SIN & SON & NAY \\
Mangrove area $\left(\mathrm{km}^{2}\right)$ & 44 & 32 & 52 & 437 \\
Substrate & $\begin{array}{c}\text { Muddy sand } \\
\text { bottom }\end{array}$ & $\begin{array}{c}\text { Muddy sand } \\
\text { bottom }\end{array}$ & $\begin{array}{c}\text { Muddy sand } \\
\text { bottom }\end{array}$ & $\begin{array}{c}\text { Muddy sand } \\
\text { bottom }\end{array}$ \\
Salinity & 39 & 34 & 38 & 24 \\
Evaporation $\left(\mathrm{mm} \cdot \mathrm{yr}^{-1}\right)$ & $1,996.5$ & $1,857.6$ & $2,716.0$ & $1,900.0$ \\
Temperature $\left({ }^{\circ} \mathrm{C}, \mathrm{max}\right)$ & 31 & 32 & 31 & 22 \\
Temperature $\left({ }^{\circ} \mathrm{C}, \mathrm{min}\right)$ & 16 & 18 & 17 & 18 \\
Rainfall $\left(\mathrm{mm} \cdot \mathrm{yr}^{-1}\right)$ & 182.6 & 650 & 253.4 & $1,500.0$ \\
\hline
\end{tabular}

*RAMSAR (2008), Félix-Pico et al. (2011), Vázquez-Botello (2011), Payan-Alejo (2012), CONABIO (2013), Payan-Alcacio (2015), Padilla-Serrato et al. (2017).

** Site codes are BCS, Baja California Sur; SIN, Sinaloa; SON, Sonora; and NAY, Nayarit. 
the Central GC (sensu Brusca et al. 2005) between 24 $07^{\prime}$ and $24^{\circ} 21^{\prime} \mathrm{N}$ and $110^{\circ} 17^{\prime}$ and $110^{\circ} 40^{\prime} \mathrm{W}$. Bahía de la Paz has several mangrove patches, with different substrate conditions. The bay has a surface area of $45 \mathrm{~km}^{2}$ and a maximum depth of $450 \mathrm{~m}$, although the depth of the selected mangroves is shallow $(2 \mathrm{~m})$. Annual rainfall is around $200 \mathrm{~mm}$. Santa María-La Reforma (Ramsar designation date 02 February 2009 , No. 2025) is found on the western coast of the state of Sinaloa (SIN) in the region of the Southern GC. It is located between $24^{\circ} 43^{\prime}$ and $25^{\circ} 15^{\prime} \mathrm{N}$ and $107^{\circ} 55^{\prime}$ and $108^{\circ} 26^{\prime} \mathrm{W}$, with a surface area of $40 \mathrm{~km}^{2}$ and depths ranging from 0.5 to $32.0 \mathrm{~m}$. This location is protected by sandy barriers formed by the action of the ocean currents, and annual rainfall there is $650 \mathrm{~mm}$. Las Guásimas (Ramsar designation date $02 \mathrm{Feb}-$ ruary 2008 , No. 1790) is a coastal lagoon located on the eastern coast of the $\mathrm{GC}$ in the southern region of the state of Sonora (SON) between $27^{\circ} 49^{\prime}$ and $27^{\circ} 55^{\prime} \mathrm{N}$ and $110^{\circ} 29^{\prime}$ and $110^{\circ} 45^{\prime} \mathrm{W}$. This is a shallow lagoon $(0.7 \mathrm{~m}$ average depth) with a surface area of $37 \mathrm{~km}^{2}$ and it is protected by 2 sand barriers that separate the water body from the sea, with $250 \mathrm{~mm}$ of annual rainfall (Fig. 1).

The fourth site is an estuarine location and was selected to test the first hypothesis. The differences between the 3 target arid localities and this site provide the opportunity to compare if the functional structure of fish is driven by more elusive conditions in tropical environments (e.g., greater presence of freshwater, lower evaporation rates), and how this could change the functional and taxonomic diversity of the fish community. Marismas Nacionales is one of the most important mangrove sites on the Pacific coast of Mexico because of its diversity and productivity (Ramsar designation date 22 June 1995, No. 732; CONABIO 2009). It is located to the south and outside of the $\mathrm{GC}$ region in the state of Nayarit (NAY), between $21^{\circ} 30^{\prime}$ and $23^{\circ} 51^{\prime} \mathrm{N}$ and $105^{\circ} 14^{\prime}$ and $106^{\circ} 01^{\prime} \mathrm{W}$. This is a subhumid site with estuarine conditions that receives a supply of freshwater from different rivers year-round, and an annual rainfall of $1,500 \mathrm{~mm}$.

\section{Species composition}

In BCS, fish composition was determined from monthly field samples (2010-2011) in 4 sites within 2 localities using a beach seine $(50 \times 3 \mathrm{~m}$; mesh size: $1 \mathrm{~cm})$. At each sampling site, 2 hauls were collected during high tide. For the other localities, species lists were extracted from the scientific literature for SIN (Payan-Alejo 2012), SON (Padilla-Serrato et al. 2016), and NAY (CONABIO 2009). All surveys from the literature followed systematic seasonal sampling lasting a yearlong and used seine nets and in some cases fish trawling to increase species detection effort. All extractions were done near the mangroves, an aspect that limits the maximum depth at which sampling can be performed. In the end, the overall sampling effort portrayed the ichthyofauna of each site in a similar way, allowing for analysis based on the presence and absence of species per location.
Adicionalmente, los sitios carecen de aportes permanentes de agua dulce provenientes de ríos, y consecuentemente, los árboles de mangle tienden a ser enanos; la profundidad del agua en el borde costero del manglar tiende a ser relativamente somera, con un régimen de mareas semidiurno. Las especies más comunes de mangle son Rhizophora mangle, Avicennia germinans, y Laguncularia racemosa (PayanAlejo 2012, Padilla-Serrato et al. 2016).

Bahía de La Paz (Baja California Sur, BCS) es el sistema costero protegido más grande en la sección este de la península de Baja California. Se localiza en la región suroeste de la parte central del GC (sensu Brusca et al. 2005) entre $24^{\circ} 07^{\prime}$ y $24^{\circ} 21^{\prime} \mathrm{N}$ y $110^{\circ} 17^{\prime}$ y $110^{\circ} 40^{\prime} \mathrm{W}$. La bahía de La Paz presenta varios parches de manglar, con diferentes condiciones en su sustrato. La bahía tiene un área de $45 \mathrm{~km}^{2}$ y una profundidad máxima de $450 \mathrm{~m}$, aunque la profundidad de los manglares seleccionados es somera $(2 \mathrm{~m})$. La precipitación anual es de alrededor de $200 \mathrm{~mm}$. Santa María-La Reforma (fecha de designación Ramsar 02 de febrero de 2009, No. 2025) se encuentra en el litoral occidental del estado de Sinaloa (SIN) en la región del sur del GC. Se localiza entre $24^{\circ} 43^{\prime}$ y $25^{\circ} 15^{\prime} \mathrm{N}$ y $107^{\circ} 55^{\prime}$ y $108^{\circ} 26^{\prime} \mathrm{W}$, con un área de $40 \mathrm{~km}^{2}$ y profundidades de 0.5 a $32.0 \mathrm{~m}$. Este sitio está protegido por una barreras arenosas formadas por la acción de las corrientes marinas, y presenta una precipitación anual de $650 \mathrm{~mm}$. Las Guásimas (fecha de designación Ramsar 02 de febrero de 2008, No. 1790) es una laguna costera también localizada en la costa este del GC, en la parte sur del estado de Sonora (SON), entre $27^{\circ} 49^{\prime}$ y $27^{\circ} 55^{\prime} \mathrm{N}$ y $110^{\circ} 29^{\prime}$ y $110^{\circ} 45^{\prime} \mathrm{W}$. Es una laguna somera ( $0.7 \mathrm{~m}$ de profundidad promedio) con un área superficial de $37 \mathrm{~km}^{2}$ protegida por 2 barreras arenosas que separan el cuerpo de agua de la parte marina, con precipitación anual de $250 \mathrm{~mm}$ (Fig. 1).

El cuarto sitio es una localidad estuarina y se seleccionó para evaluar la primera hipótesis. Las diferencias entre las 3 localidades áridas objetivo y este sitio dieron la oportunidad de comparar si la estructura funcional de los peces es dirigida por condiciones más elusivas en un ambiente tropical (e.g., mayor presencia dulceacuícola y menores tasas de evaporación), y cómo esto puede cambiar la diversidad taxonómica y funcional de la comunidad de peces. Marismas Nacionales es uno de los sitios de manglar más importantes en la costa mexicana del Pacífico debido a su productividad y diversidad (fecha de designación Ramsar 22 de junio de 1995, No. 732; CONABIO 2009). Se localiza al sur y fuera de la región del GC, en el estado de Nayarit (NAY), entre $21^{\circ} 30^{\prime}$ y $23^{\circ} 51^{\prime} \mathrm{N}$ y $105^{\circ} 14^{\prime}$ y $106^{\circ} 01^{\prime} \mathrm{W}$. Es un sitio semi-húmedo con condiciones estuarinas que recibe aportes dulceacuícolas por parte de ríos todo el año, y tiene una precipitación anual de $1,500 \mathrm{~mm}$.

\section{Composición de las especies}

En BCS, la composición de peces fue determinada a partir de muestreos mensuales (2010-2011) en 4 sitios dentro de 


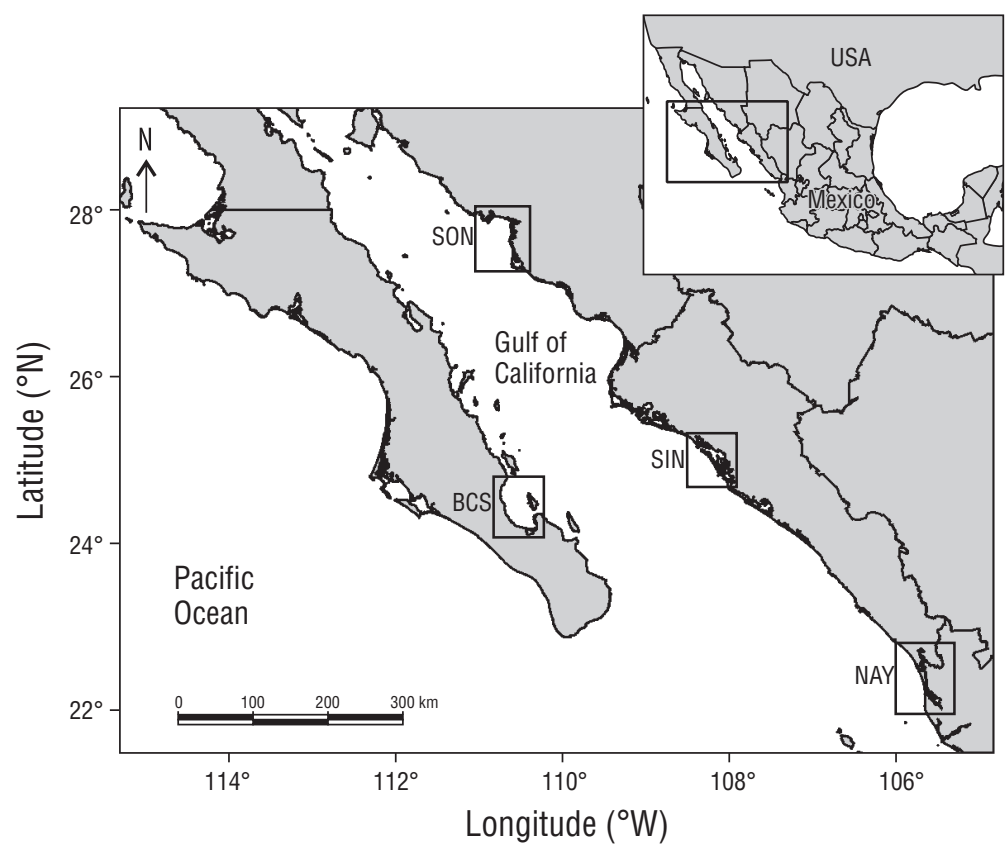

Figure 1. Map of the locations within the Gulf of California. Baja California Sur (BCS), Sinaloa (SIN), Sonora (SON), and Nayarit (NAY). Figura 1. Mapa de las localidades dentro del golfo de California. Baja California Sur (BCS), Sinaloa (SIN), Sonora (SON), and Nayarit (NAY).

Analysis of similarity (ANOSIM) was used to test for differences in species composition similarity among sites and between sites (BCS, SIN, SON, and NAY). ANOSIM is a nonparametric test that uses a rank dissimilarity (Jaccard distance), where random iterations of the relationship between 2 objects are calculated and the resulting values range from -1 to 1 ; values closer to 1 indicate statistical difference between groups, while values closer to 0 indicate that the relationships are no different from a random construction. We separated 2 groups, the arid locations in one (BCS, SIN, and SON) and NAY in the second. Six random re-samples from NAY were required in order to generate enough data to create the second group, from which we ran 999 permutations of the analysis (Clarke 1993).

\section{Functional data}

Representative photographs of each species were obtained from specialized fish webpages (e.g., FishBase, https:// www.fishbase.de/; Naturalista, https://www.naturalista.mx/). Five species were not considered in the analysis because available photographs did not match the quality criteria to be selected. Using ImageJ software (National Institutes of Health, Bethesda, Maryland, USA; http://imagej.nih.gov/ij/), 19 homologous points were digitized in each photo (Fig. 2). From such points, 13 measurements (heights and lengths) were calculated for each species (Table 2). Finally, a total of 11 functional traits were obtained, which were derived from the proportions between measurements (Table 3). The traits were selected from those proposed by Villéger et al.
2 localidades usando un chinchorro playero $(50 \times 3 \mathrm{~m}$; apertura de malla: $1 \mathrm{~cm}$ ). En cada sitio de muestreo se realizaron 2 arrastres durante la marea alta. Para las otras localidades, la lista de especies fue extraída de la literatura científica para SIN (Payan-Alejo 2012), SON (Padilla-Serrato et al. 2016) y NAY (CONABIO 2009). Todos los estudios citados siguieron un muestreo sistemático estacional durante un año, y usaron redes de arrastre y, en algunos casos, arrastres camaroneros con la finalidad de incrementar la detección de especies. Todas las capturas se realizaron cerca de la sección de mangle, factor que limitó la máxima profundidad a la cual se pudo realizar el muestreo. Al final de cuentas, todos los muestreos describieron la ictiofauna para cada sitio de manera similar, lo que permitió el análisis con base en la presencia y ausencia de las especies por localidad.

El análisis de similitud (ANOSIM) fue utilizado para probar diferencias en la similitud de la composición de especies entre los sitios y las regiones (BCS, SIN, SON y NAY). Esta es una prueba no paramétrica que usa rangos de disimilitud (índice de Jaccard), donde las iteraciones aleatorias sobre la relación entre 2 objetos son calculadas y los resultados varían en un intervalo de -1 a 1 ; los valores cercanos a 1 indican diferencias estadísticas entre los grupos, mientras que valores cercanos a 0 indican que las relaciones estadísticas entre los grupos no son diferentes de una construcción aleatoria. Se separaron 2 grupos, las localidades áridas en uno (BCS, SIN y SON) y NAY en el segundo. Se realizaron 6 remuestreos aleatorios de NAY con la finalidad de crear suficiente información para el segundo grupo, para el cual se corrieron 999 permutaciones en el análisis (Clarke 1993). 
(2010) and Soares et al. (2013) to best represent the strategies of fish species in relation to food acquisition, habitat, and locomotion. Correlation tables were used to identify and exclude those variables that were highly correlated with one another (Pearson coefficients $>0.80$ ), to avoid overestimation of the process that is represented in the functional attribute. From the remaining variables, a principal component analysis was used to identify those that were most significant in explaining the trait variation in the regional species pool (Houseman and Gross 2011). As long as trait selection is representative of species performance (Villéger et al. 2017), functional diversity indices are more reliable measures describing communities using even a small number of samples (Bady et al. 2005).

Some authors have suggested modifying the measurement procedure to reduce the variability in the measurements of the most extreme morphologies (e.g., flatfishes) (Toussaint et al. 2016). However, we decided not to do so since it is important to consider differences in morphology for a better understanding of the ecological processes studied (Toussaint et al. 2016).

\section{Functional space}

To create a multidimensional functional space from the traits selected, an affinity matrix using the Euclidean distance was calculated. Then, with the resulting matrix, a principal coordinate analysis (PCoA) was performed and results from the species coordinates were interpreted for the first 5 axes (Buisson et al. 2012).

\section{Functional indices}

The functionality of the fish community was characterized using the functional richness (FRic, Villéger et al. 2010), functional dispersion (FDis, Laliberté and Legendre 2010), and functional redundancy (FRed, Bello et al. 2007). Using

\section{Datos funcionales}

Fotografías representativas de cada especie fueron obtenidas de páginas web especializadas en peces (e.g., FishBase, https://www.fishbase.de/; Naturalista, https://www. naturalista.mx/). Cinco especies no fueron consideradas en el análisis porque las fotografías disponibles no cumplían con el criterio de calidad establecido para su selección. Con el uso del software ImageJ (National Institutes of Health, Bethesda, Maryland, EUA; http://imagej.nih.gov/ij/), se digitalizaron 19 puntos homólogos en cada una de las fotografías (Fig. 2). A partir de esos puntos, 13 medidas (alturas y longitudes) se calcularon para cada especie (Tabla 2). Finalmente, un total de 11 atributos funcionales fueron obtenidos, que fueron derivados de las proporciones entre las medidas (Tabla 3). Los atributos fueron seleccionados de aquellos propuestos por Villéger et al. (2010) y Soares et al. (2013) para representar de la mejor manera las estrategias de los peces en relación con la obtención de su alimento, el hábitat y la locomoción. Se utilizaron tablas de correlación para identificar y remover aquellas variables que se encontraban altamente relacionadas entre sí (coeficientes de Pearson $>0.80$ ), con el fin de evitar la magnificación del proceso que se representaba en el atributo funcional. Con las variables restantes, se utilizó un análisis de componentes principales para identificar aquellas con mayor significancia para explicar la variación de los atributos en el grupo regional de las especies (Houseman y Gross 2011). En la medida que la selección de los atributos sea representativa del desempeño de las especies (Villéger et al. 2017), los índices de diversidad funcional serán medidas más confiables para describir la comunidad, aunque se utilice un pequeño número de muestras (Bady et al. 2005).

Algunos autores han sugerido modificar los procesos de medición para reducir la variabilidad entre las medidas de las morfologías más extremas (e.g., lenguados) (Toussaint et al. 2016). Sin embargo, se decidió no cambiarlas porque es importante considerar la diferencia en las morfologías para

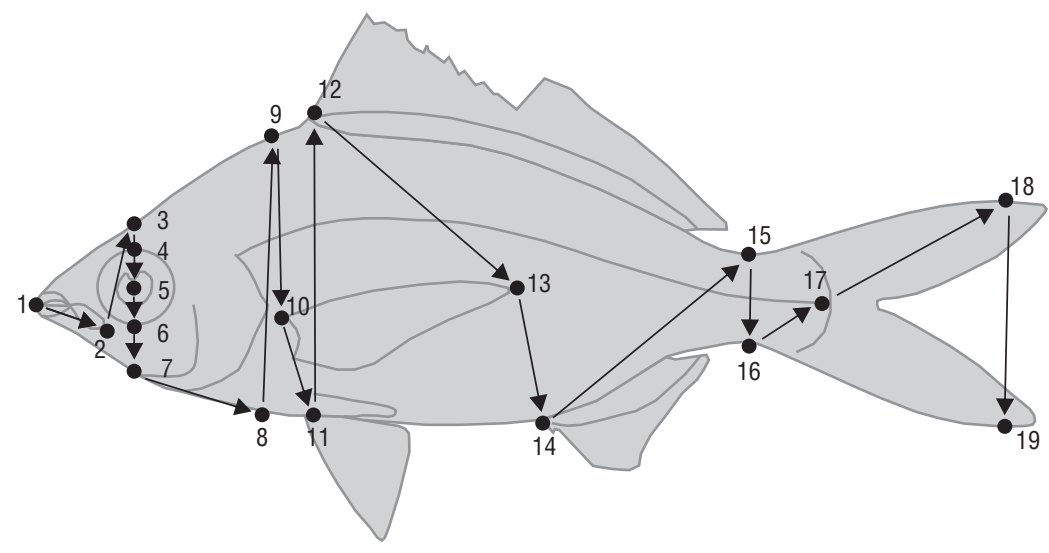

Figure 2. Set of homologous points measured in every species.

Figura 2. Registro de los puntos homólogos medidos en cada especie. 
Payan-Alcacio et al.: Fish functional diversity in arid mangroves

Table 2. Measurements obtained from the photographs.

Tabla 2. Medidas obtenidas a partir de las fotografías.

\begin{tabular}{lccc|}
\hline Measure & Acronym & Point A & Point B \\
\hline Standard length & $\mathrm{Sl}$ & 1 & 17 \\
Maximum body height & $\mathrm{Bh}$ & 11 & 12 \\
Head height & $\mathrm{Hh}$ & 8 & 9 \\
Head length & $\mathrm{Hl}$ & 1 & 8 \\
Eye diameter & $\mathrm{Ed}$ & 4 & 6 \\
Eye position & $\mathrm{Ep}$ & 5 & 11 \\
Jaw length & $\mathrm{Jl}$ & 1 & 2 \\
Mouth position & $\mathrm{Mp}$ & 1 & 11 \\
Pectoral fin length & $\mathrm{PFl}$ & 1 & 13 \\
Pectoral fin insertion & $\mathrm{Pfi}$ & 10 & 11 \\
Caudal peduncle height & $\mathrm{CPh}$ & 15 & 16 \\
Caudal peduncle length & $\mathrm{CPl}$ & 15 & 17 \\
Caudal fin height & $\mathrm{CFh}$ & 18 & 19 \\
\hline
\end{tabular}

the R statistical language (v.3.6.1, R Core Team 2019), the first 2 indices were calculated with the multidimFD package (Villéger et al. 2017) and functional redundancy was calculated with the SYNCSA package (Debastiani and Pillar 2012).

To test our first hypothesis, functional richness was used to refer to the ecological niche occupied by species within a community (Mason et al. 2005). Functional dispersion is the weighted mean distance in the multidimensional trait space of individual species to the centroids (Laliberté and Legendre 2010), and it works as a complementary analysis to understand the distance of the traits from the center of the functional space. Both indices allowed us to create the baseline of the traits present in the community and to understand how the assembly process could be shaped.

\section{Environmental and biotic interactions}

With the aim of relating these traits to environmental conditions such as salinity, maximum and minimum temperature, type of substrate, precipitation rate, evaporation rate, precipitation deficit (precipitation rate - evaporation rate; $\mathrm{mm} \cdot \mathrm{yr}^{-1}$ ), and mangrove coverage area, distance-based redundancy analysis with Jaccard distance was used. The analysis uses PCoA eigenvalues into a redundancy analysis, allowing us to identify the relationship between multiple variables $x$ and $y$ in a non-symmetrical way. The analysis was processed with the function capscale of the package vegan in R (v.3.6.1, R Core Team 2019). Additionally, we described the environmental characteristics of each site from scientific publications and specialized fish webpages to corroborate this relationship (e.g., Castro-Aguirre et al. 1999; FishBase, https://www.fishbase.de/). entender mejor los procesos ecológicos estudiados (Toussaint et al. 2016).

\section{Espacio funcional}

Para crear un espacio funcional multidimensional a partir de los atributos seleccionados, se calculó una matriz de afinidad utilizando distancias euclidianas. Posteriormente, con la matriz resultante, se realizó un análisis de coordenadas principales (PCoA, por sus siglas en inglés) y se interpretaron los resultados de las coordenadas de las especies para los primeros 5 ejes (Buisson et al. 2012).

\section{Índices funcionales}

La funcionalidad de la comunidad de peces fue caracterizada utilizando la riqueza funcional (FRic, Villéger et al. 2010), la dispersión funcional (FDis, Laliberté y Legendre 2010) y la redundancia funcional (FRed, Bello et al. 2007). Con el lenguaje estadístico R (v.3.6.1, R Core Team 2019), los primeros 2 índices fueron calculados con el paquete multidimFD (Villéger et al. 2017) y la redundancia funcional fue calculada con el paquete SYNCSA (Debastiani y Pillar 2012).

Con el fin de probar nuestra primera hipótesis, se utilizó la riqueza funcional para referirnos al nicho ecológico ocupado por las especies dentro de la comunidad (Mason et al. 2005). La dispersión funcional es la distancia media ponderada en el espacio multidimensional de las especies al centroide (Laliberté y Legendre 2010), y funciona como un análisis complementario para entender la distancia de los atributos al centro del espacio funcional. Ambos índices nos permitieron crear una línea base de los atributos presentes en 


\section{Specialized traits}

In order to verify our second hypothesis and detect the specialized traits in the communities, functional redundancy analysis was selected to represent the maximum saturation of species with similar traits that are found in a given community; a zero value indicated that all the species are functionally different, in contrast to a value of one, which indicated that all the species shared similar traits in the community (Ricotta et al. 2016).

To complement the detection of the specialized traits, a taxonomic distinctness analysis was used to add another perspective into the differences in the community structure. As less taxa are found, it is most likely that the community would be represented by dominant traits, pointing out to a specialized community. This technique calculates the average distance based on the species phylogenetic tree of the locality, pairing all the species together (Clarke and Warwick 1999) based on their taxonomic relationships (species, genus, family, order, and class). The nature of this technique has proven effective in overcoming the limitation of comparing sites with different sampling efforts, by a resampling process of the "regional" pool of the species and the mathematical pairing of the analysis. An a posteriori test was used to detect the statistical similarity in the taxonomic structure of the sites, through the respective indices calculated from random subsets of communities to create a probability funnel, in which the localities are positioned; the ones outside the funnel are considered statistically different (Clarke and Warwick 1999). The analyses were performed using PRIMER software (v.6, Clarke and Gorley 2006).

Table 3. Formulas for calculating functional attributes.

Tabla 3. Fórmulas para calcular los atributos funcionales.

\begin{tabular}{lcc}
\hline Attribute & Acronym & Formula* \\
\hline Body elongation & $\mathrm{tBe}$ & $\mathrm{Bh} / \mathrm{Sl}$ \\
Body form & $\mathrm{tBf}$ & $\mathrm{Hl} / \mathrm{Sl}$ \\
Body height & $\mathrm{tBh}$ & $\mathrm{Hh} / \mathrm{Bh}$ \\
Oral gape position & $\mathrm{tOGp}$ & $\mathrm{Mp} / \mathrm{Hh}$ \\
Mouth length & $\mathrm{tMl}$ & $\mathrm{Jl} / \mathrm{Hl}$ \\
Eye size & $\mathrm{tEl}$ & $\mathrm{Ed} / \mathrm{Hh}$ \\
Eye orientation & $\mathrm{tEp}$ & $\mathrm{Ep} / \mathrm{Hh}$ \\
Pectoral fin size & $\mathrm{tPFa}$ & $\mathrm{PFl} / \mathrm{Sl}$ \\
Pectoral fin position & $\mathrm{tPFp}$ & $\mathrm{PFi} / \mathrm{Bh}$ \\
Caudal penducle throttling & $\mathrm{tCPt}$ & $\mathrm{CPh} / \mathrm{CFh}$ \\
Caudal penducle aspect & $\mathrm{tCPa}$ & $\mathrm{CPh} / \mathrm{CPl}$ \\
\hline
\end{tabular}

*See Table 2 for definitions of abbreviations used in the formulas. la comunidad y entender cómo el proceso de ensamblaje se podría representar.

\section{Interacciones bióticas y ambientales}

Con el objetivo de relacionar los atributos a las condiciones ambientales como la salinidad, la temperatura máxima y mínima, el tipo de sustrato, la tasa de precipitación, la tasa de evaporación, el déficit de precipitación (tasa de precipitación - tasa de evaporación; $\mathrm{mm} \cdot \mathrm{año}^{-1}$ ) y la cobertura del área de manglar, se utilizó un análisis de redundancia basado en distancias con el índice de Jaccard. El análisis usa eigenvalores de PCoA dentro de un análisis de redundancia, lo cual permite identificar la relación entre múltiples variables $x$ e $y$ de forma no simétrica. El análisis fue realizado con la función capscale del paquete Vegan en R (v.3.6.1, R Core Team 2019). Adicionalmente, se describieron las características ambientales donde se presentan las especies, a partir de publicaciones científicas y páginas especializadas en peces, para corroborar las relaciones encontradas (e.g., CastroAguirre et al. 1999; FishBase, https://www.fishbase.de/).

\section{Atributos especializados}

Con el objetivo de verificar la segunda hipótesis y detectar atributos especializados en las comunidades, se seleccionó el análisis de redundancia funcional para identificar la máxima saturación de especies con atributos similares dentro de una comunidad dada; un valor de cero indicó que todas las especies son funcionalmente diferentes, en contraste con el valor de uno, que indicó que todas las especies comparten los mismos atributos (Ricotta et al. 2016).

Con el fin de complementar la detección de los atributos especializados, se usó un análisis de distintividad taxonómica para agregar otra perspectiva a las diferencias en la estructura de la comunidad. Mientras menos taxones se encuentren, es menor la probabilidad de que la comunidad esté dirigida por atributos dominantes, lo que indica una comunidad especializada. Esta técnica calcula la distancia promedio dentro de un árbol filogenético de las especies en una localidad, emparejándolas todas (Clarke y Warwick 1999) con base en sus relaciones taxonómicas (especie, genero, familia, orden y clase). La naturaleza de esta técnica ha demostrado ser efectiva para superar la limitación de las comparaciones de sitios con diferentes esfuerzos de muestreo, mediante un proceso de remuestreo del grupo "regional" de las especies y la técnica de emparejamiento matemático del análisis. Se utilizó una prueba a posteriori para detectar la similitud estadística en la estructura taxonómica de los sitios, a través de los índices calculados a partir de subconjuntos aleatorios de comunidades para crear un túnel de probabilidad, en el que las localidades están posicionadas; aquellas localidades fuera del túnel se consideran estadísticamente diferentes (Clarke y Warwick 1999). Los análisis se realizaron con el software PRIMER (v.6, Clarke y Gorley 2006). 
Payan-Alcacio et al.: Fish functional diversity in arid mangroves

\section{Results}

\section{Species richness}

A total of 123 species were identified in the arid mangrove habitats in the GC region in northwest Mexico. Specifically, 69 species were found in Las Guásimas (SON), 58 in Santa María-La Reforma (SIN), and 50 in La Paz Bay (BCS). We found 12 shared species within 9 families across these localities: Haemulidae ( 3 spp.), Lutjanidae (2 spp.), Ephippidae, Gerreidae, Gobiidae, Mugilidae, Paralichthyidae, Synodontidae, and Tetraodontidae (one species each). For each pair of localities in the gulf, at least 8 to 9 species were shared (SIN-SON, SON-BCS, and BCS-SIN). Marismas Nacionales (NAY) is represented by 111 species, with 10 species in common with the species pool of the GC sites. It shares species from 8 out of 9 families with the exception of Gobiidae, with 59 exclusive species. ANOSIM detected differences between the arid mangrove sites and the external community $(R=0.951, P=0.007)$.

\section{Functionality}

The variables that defined the grouping of the functional space in the community were the position of the mouth, aspect of the caudal peduncle, and position of the eye. The explained variance for the 4 localities was $95 \%$ in the first 5 ordination axes.

The results pertinent to the first hypothesis were that functional richness and dispersion presented the highest values in SON because of a higher diversity of species traits related to the presence of flatfishes in the community (Fig. 3). There was a large clustering of species from the order Perciformes in the middle of the functional space for all localities, where the attributes tended to be redundant because of their similar morphologies (perch-shape). Outside the cluster of redundancy, the nearest points are related to benthic species (Gobiidae, Tetraodontidae), while the farthest points are related to the morphology of flatfishes. The NAY locality, on the other hand, presented the lowest functional values for richness and dispersion because of its estuarine condition.

The distance-based redundancy analysis detected 3 separate groups among the sites analyzed and the environmental factors. In the first axis, there was a salinity gradient with the arid locations closely associated with higher values, BCS and SIN presented similar salinity concentrations, and NAY had lower salinity. The variable related to the surface area describes how NAY (with the highest richness) was related to a larger land extension of mangrove vegetation. Finally, in SON the community was governed by higher evaporation rates (Fig. 4).

In the description of the milieu of overall species (179 species in the 4 localities), $56 \%$ were defined as strictly marine, $32 \%$ had a marine-estuarine affinity, $10 \%$ were present from marine to freshwater habitats (e.g., Achirus mazatlanus,

\section{RESUltados}

\section{Riqueza específica}

Se identificaron un total de 123 especies en los hábitats áridos de manglar para la región del GC en el noroeste de México. Específicamente, se encontraron 69 especies en Las Guásimas (SON), 58 en Santa María-La Reforma (SIN) y 50 en bahía de La Paz (BCS). Se encontraron 12 especies compartidas dentro de 9 familias en estas localidades: Haemulidae (3 spp.), Lutjanidae (2 spp.), Ephippidae, Gerreidae, Gobiidae, Mugilidae, Paralichthyidae, Synodontidae y Tetraodontidae ( $1 \mathrm{sp}$. cada uno). Para cada par de localidades en el golfo, se compartieron entre 8 y 9 especies (SIN-SON, SON-BCS y BCS-SIN). Marismas Nacionales (NAY) está representada por 111 especies, con 10 especies en común con el conjunto de especies de los sitios del GC. Esta localidad comparte especies en 8 de 9 familias a excepción de Gobiidae, y tiene 59 especies exclusivas. El ANOSIM detectó diferencias entre los sitios de manglar áridos y la comunidad externa $(R=0.951, P=0.007)$.

\section{Funcionalidad}

Las variables que definieron los agrupamientos en el espacio funcional de la comunidad fueron la posición de la boca, el aspecto del pedúnculo caudal y la posición del ojo. La varianza explicada para las 4 localidades fue del $95 \%$ en los primeros 5 ejes de ordenación.

Los resultados para la primera predicción fueron que la riqueza funcional y la dispersión presentaron los valores más altos en SON debido a una mayor diversidad de atributos de las especies relacionados con la presencia de lenguados en la comunidad (Fig. 3). Se obtuvo un gran agrupamiento de especies del orden Perciformes en la mitad del espacio funcional para todas las localidades, donde los atributos tendieron a ser redundantes debido a sus morfologías similares (forma de percas). Fuera del grupo de redundancia, los puntos más cercanos están relacionados con especies bentónicas (Gobiidae, Tetraodontidae), mientras que los puntos más alejados están relacionados con la morfología de los lenguados. La localidad de NAY, por su parte, presentó los valores funcionales más bajos de riqueza y dispersión debido a su condición estuarina.

El análisis de redundancia basado en distancias detectó 3 grupos separados entre los sitios analizados y los factores ambientales. En el primer eje, hubo un gradiente de salinidad con las localidades áridas estrechamente asociadas con valores más altos, BCS y SIN presentaron altas concentraciones de salinidad y NAY presentó menor salinidad. La variable de superficie describe cómo el sitio NAY (que presentó la mayor riqueza de especies) se relacionó principalmente con una mayor extensión de vegetación de manglar. Finalmente, en SON la comunidad estuvo condicionada por las tasas de evaporación más altas (Fig. 4). 

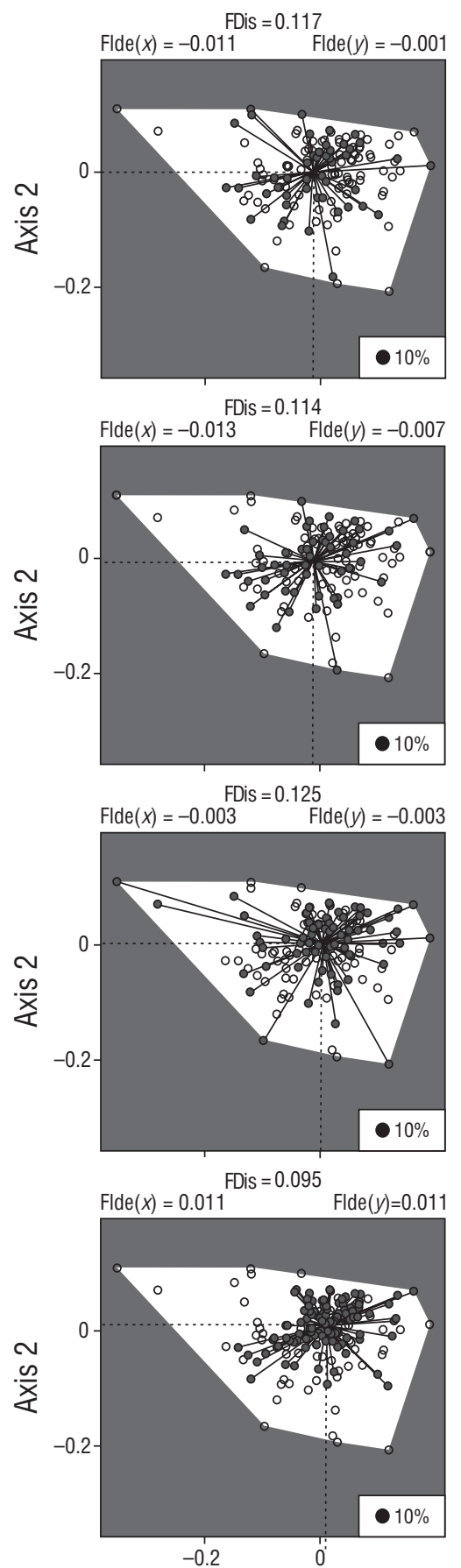

Axis 1

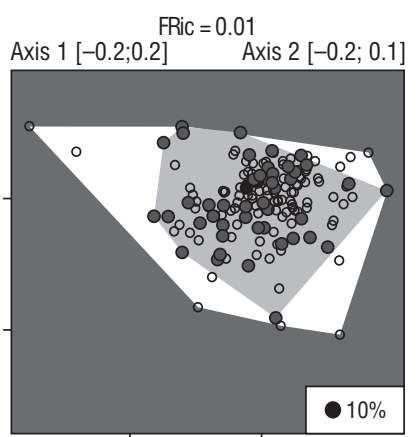

BCS

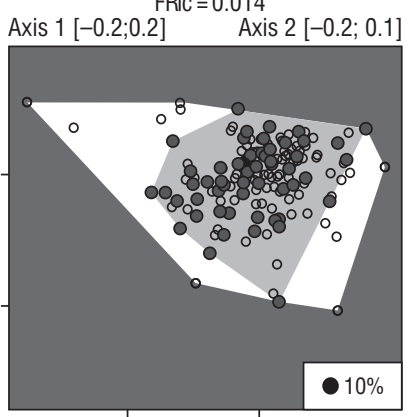

SIN

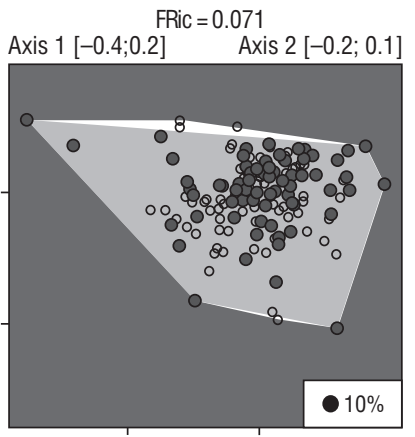

SON
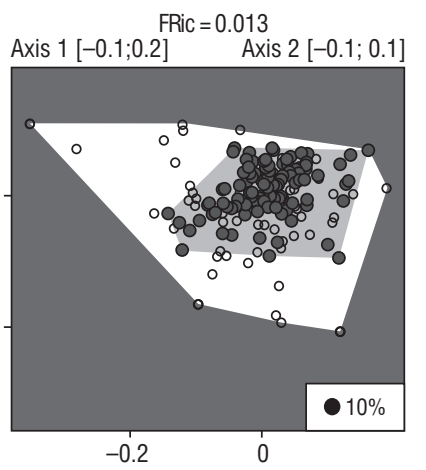

Axis 1

Figure 3. Principal coordinate analysis for functional dispersion (FDis) and functional richness (FRic) in each locality: Baja California Sur (BCS), Sinaloa (SIN), Sonora (SON), and Nayarit (NAY). The functional space of the mangrove fishes in the Gulf of California represents the species distributed along the first and second axes using 11 functional traits. The clear polygon represents the functional space of the total pool of species at all localities, while the smaller polygon (shaded) represents the functional space at each locality. The explained variability in the axis is $60.0 \%$ for BCS, $57.9 \%$ for NAY, $52.3 \%$ for SON, and $49.3 \%$ for SIN. In general, the northern localities had higher values in both indices than the southern locality (NAY).

Figura 3. Análisis de coordenadas principales para la dispersión funcional (FDis) y la riqueza funcional (FRic) por localidad: Baja California Sur (BCS), Sinaloa (SIN), Sonora (SON) y Nayarit (NAY). El espacio funcional de los peces de manglar en el golfo de California representa las especies distribuidas a lo largo del primer y segundo eje usando 11 atributos funcionales. El polígono claro representa el espacio funcional del conjunto total de especies en todas las localidades, mientras que el polígono de menor dimensión (sombreado) representa el espacio funcional de cada localidad. La variabilidad explicada en el eje va del $60.0 \%$ para BCS, $57.9 \%$ para NAY, 52.3\% para SON y $49.3 \%$ para SIN. En general, las localidades norteñas presentaron mayores valores en ambos índices que la localidad más sureña (NAY). 
Eucinostomus currani, Gerres cinereus, Mugil curema, and Mugil cephalus), and 2\% were peripheral with continuous migration from the sea into the river (e.g., Colpichthys hubbsi and Colpichthys regis). Only one introduced species of freshwater origin was found in NAY (Oreochromis aureus). Regarding the species with wide salinity tolerance, $6,8,11$, and 16 species were found in the SON, BCS, SIN, and NAY sites, respectively. In the case of the species that occurred at all sites (11 spp.), those with marine-estuarine affinity were the most common (5 spp.), followed by those that were strictly marine ( $3 \mathrm{spp}$.), and finally those with an affinity to all environments ( $3 \mathrm{spp}$.).

The results related to the second hypothesis showed that functional redundancy had similar results for all localities with overlap in the community's functional space, with an increasing gradient starting from the northern to the southern localities (SON: 0.586; BCS: 0.595; SIN: 0.600; and NAY: 0.641 ). The taxonomic diversity showed significant statistical variation in the taxonomic composition of the localities within the GC because SIN was outside the probabilistic funnel. However, if we compare the position of NAY, there is a higher level of variance within this location (Fig. 5). Additionally, this analysis showed that the organizational levels with the greatest probability of change were found at the taxonomic level of order.

\section{Discussion}

Using a functional approach for the analysis of the fish community at different sites in the GC, we found that the communities seem to show functional overlap due to the similarities in the arid conditions of the mangrove ecosystem of northwest Mexico (López-Medellín and Ezcurra 2012). In terms of our hypotheses, contrary to the first one, we did not find trait uniqueness for each locality, but a high similarity in the ecoregion functional structure. We found that the high functional similarity in community structure could be related to the similar use of the mangroves by fishes in the gulf. Since coastal fishes usually look for shelter in protected areas (Sheaves 2017), the few mangrove sites available along the GC (CONABIO 2009) have a higher importance as nursery grounds for the juveniles than other coastal zones and ecosystems along the region (Álvarez-Romero et al. 2013). Additionally, these habitats attract opportunistic predators, as has been reported for some species (Oligoplites altus and Auxis thazard) in the warm season in locations within La Paz Bay, BCS (González-Acosta et al. 2005), and SON (Padilla-Serrato et al. 2017). In addition, it is probable that the functional filtering factor for estuarine fish communities is higher than high-salinity sites because of the physiological conditions needed to withstand greater variations in the water conditions of an estuarine environment.

According to the hypothesis that drier environmental conditions promote higher presence of more specialized species, the results supported this statement with lower redundancy
En la descripción de la afinidad ambiental de las especies (179 especies en las 4 localidades), el 56\% de estas se definieron como estrictamente marinas, el $32 \%$ tuvo una afinidad marino-estuarina, el 10\% estuvo presente en hábitats marinos y hasta en los de agua dulce (e.g., Achirus mazatlanus, Eucinostomus currani, Gerres cinereus, Mugil curema y Mugil cephalus) y el $2 \%$ eran periféricos con migración continua desde el mar hacia el río (e.g., Colpichthys hubbsi, Colpichthys regis). Solo se encontró una especie introducida con origen dulceacuícola en NAY (Oreochromis aureus). Con respecto a las especies con amplia tolerancia a la salinidad, se encontraron 6 en SON, 8 en BCS, 11 en SIN y 16 en NAY. En el caso de las especies que se presentaron en todos los sitios (11 spp.), aquellas con afinidad marino-estuarina fueron las más comunes ( $5 \mathrm{spp}$.), seguidas de aquellas que eran estrictamente marinas ( $3 \mathrm{spp}$.) y finalmente aquellas con afinidad a todos los ambientes (3 spp.).

Los resultados relacionados con la segunda predicción mostraron que la redundancia funcional presentó valores similares para todas las localidades con una superposición en el espacio funcional de la comunidad, con un gradiente que aumentó a partir de las localidades del norte hacia las del sur (SON: 0.586; BCS: 0.595; SIN: 0.6; y NAY: 0.641). La diversidad taxonómica mostró una variación estadística significativa en la composición taxonómica de las localidades dentro del GC porque SIN salió del túnel probabilístico. Sin embargo, si comparamos la posición de NAY, hay un mayor nivel de variación dentro de esta ubicación (Fig. 5). Adicionalmente, este análisis mostró que los niveles organizacionales con mayor probabilidad de cambio se encontraron en el nivel taxonómico de orden.

\section{Discusión}

Al utilizar un enfoque funcional para el análisis de la comunidad de peces en diferentes sitios del GC, se encontró que, debido a las similitudes en la condición árida del ecosistema de manglares del noroeste de México (López-Medellín y Ezcurra 2012), las comunidades aparentemente presentan superposición funcional. Tomando en cuenta las hipótesis, contrario a lo predicho en la primera propuesta, no se encontraron atributos únicos para cada localidad, sino una gran similitud en la estructura funcional de la ecoregión. Se encontró que la alta similitud funcional en la estructura de la comunidad puede estar relacionada con el uso semejante que hacen los peces de los manglares en el golfo. Dado que los peces costeros generalmente buscan refugio en áreas protegidas (Sheaves 2017), los pocos sitios de manglares disponibles a lo largo del GC (CONABIO 2009) tienen una mayor importancia como guarderías para los juveniles que otras zonas costeras y ecosistemas a lo largo de la región (Álvarez-Romero et al.2013). Además, estos hábitats atraen depredadores oportunistas, como se ha reportado en la estación cálida para algunas especies (Oligoplites altus y Auxis thazard) en lugares dentro de bahía de La Paz, BCS 


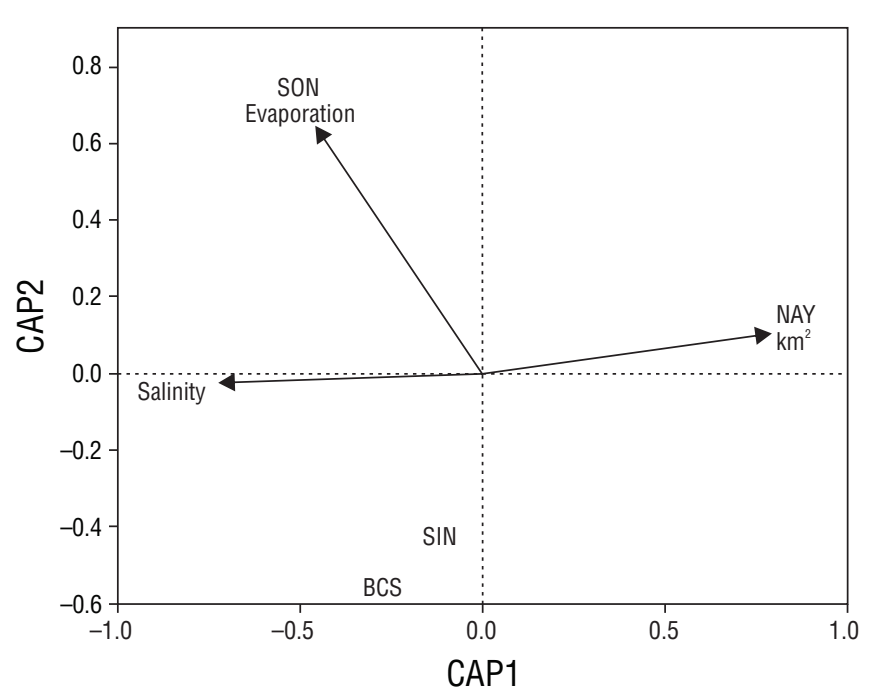

Figure 4. Distribution-based redundancy analysis ordination diagram of northwest region with environmental variables and species scores for Baja California Sur (BCS), Sinaloa (SIN), Sonora (SON), and Nayarit (NAY).

Figura 4. Diagrama de ordenación del análisis de redundancia basado en distancias de la región noroeste con los valores de las variables ambientales y las especies para Baja California Sur (BCS), Sinaloa (SIN), Sonora (SON) y Nayarit (NAY).

values in the Cortezian ecoregion. Representative fish such as flatfish, gobies, and puffers belonged to the benthic guild. Also a taxonomic latitudinal gradient seemed to be present for the mangrove fish community. Northern localities were less diverse, and SIN represented a transitional locality between the arid and semitropical conditions (NAY), probably due to more frequent riverine supply.

\section{Composition of fish communities}

A comparison of the diversity of fish species in mangroves from the GC with that of other mangroves with arid conditions worldwide (e.g., Shahraki et al. 2016) indicated that our localities ( $>55$ spp. on average) presented almost twice the richness of species than that at other sites ( $\pm 30 \mathrm{spp}$.). A possible explanation is that the GC presents temporal and spatial changes in the climatic and environmental conditions, promoting the annual and interannual signals that enable the entrance of fish species into the gulf (Escalante et al. 2013). Consequently, it is common to find species with tropical and temperate affinities (González-Acosta et al. 2005).

On the other hand, when comparing the total richness of the GC sites against NAY (111 spp.), we found reduced richness of species in northwest Mexico. For example, in NAY, the presence of marine and brackish species in the families Centropomidae, Eleotridae, and Sciaenidae was common, as was the presence of some freshwater euryhaline species like the those in the family Cichlidae. In the case of marine demersal

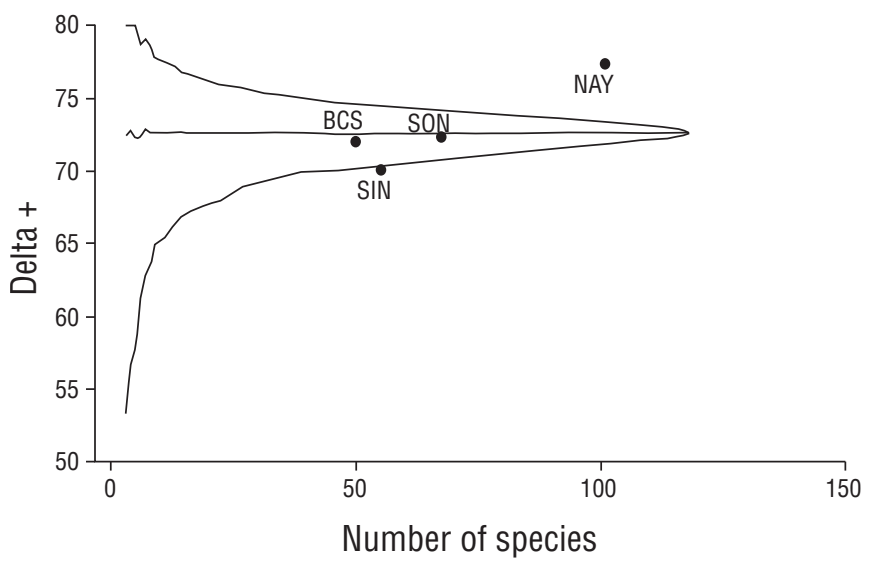

Figure 5. The probability funnel of the taxonomy shows the northwest localities of Mexico, and the ones that are inside the funnel had statistically similar taxonomic composition. Baja California Sur (BCS), Sinaloa (SIN), Sonora (SON), and Nayarit (NAY). The values with respect to the y-axis (delta + ) show the taxon level of variation of the community (order level).

Figura 5. El túnel de probabilidad taxonómica muestra las localidades del noroeste de México, y las que se encuentran dentro del túnel tuvieron una composición taxonómica estadísticamente similar. Baja California Sur (BCS), Sinaloa (SIN), Sonora (SON), y Nayarit (NAY). Los valores con respecto al eje y (delta + ) muestran el nivel taxonómico de variación de la comunidad (nivel de orden).

(González-Acosta et al. 2005) y SON (Padilla-Serrato et al. 2017). Adicionalmente, es probable que el factor de filtración funcional para las comunidades de peces estuarinos sea mayor que en los sitios de alta salinidad, debido a las condiciones fisiológicas requeridas para soportar mayores variaciones en las condiciones del agua del ambiente estuarino.

De acuerdo con la hipótesis de que las condiciones ambientales áridas promueven una mayor presencia de especies más especializadas, los resultados respaldaron esta afirmación con valores de redundancia más bajos en la ecorregión Corteziana. Los lenguados, los gobios y los botetes pertenecientes al gremio bentónico representaron esta comunidad. Además, pareció estar presente un gradiente latitudinal taxonómico para la comunidad de peces de manglar. Las localidades del norte fueron menos diversas y SIN representó una localidad de transición entre las condiciones áridas y semitropicales (NAY), probablemente debido a un suministro fluvial más frecuente.

\section{Composición de las comunidades de peces}

Cuando se compara la diversidad de las especies de peces en manglares del GC con la de otros manglares en el mundo con condiciones áridas (e.g., Shahraki et al. 2016), las localidades del presente estudio (en promedio $>55 \mathrm{spp}$.) presentan casi el doble de la riqueza de especies que en otros sitios ( $\pm 30 \mathrm{spp})$. Una posible explicación es que el GC presenta cambios temporales y espaciales en sus condiciones 
Payan-Alcacio et al.: Fish functional diversity in arid mangroves

fish, some species of Haemuidae (Anisotremus interruptus and Genyatremus dovii), Lutjanidae (Lutjanus inermis and Lutjanus jordani), and Carangidae (Carangoides otrynter) were absent in the northwest.

\section{The functional approach}

The first 2 axes in the functional space of the mangrove fish community explained a high percentage of the overall variance since almost all the species belonged to Perciformes. The traits with the higher functional explanation power were the position of the mouth and position of the eye on the first axis, both related to the feeding process. Meanwhile, the aspect of the caudal peduncle better described the second axis and is related to locomotion. Similar results were found by Soares et al. (2013) for fish communities in Brazil. However, the results of the explained variance appear to be magnified by the percentage of species present from the families Lutjanidae, Haemulidae, Sciaenidae, Serranidae, and Gerreidae (fishes with similar morphology, from now on referred as generalists). This has been reported for other fish fauna that have experienced high radiation events but had less significant differences in morphological features (Toussaint et al. 2016).

Other fish adaptations in the results showed sessile benthic species (flatfishes, the farthest species from the cluster of generalist species) on the first axis. These species are characterized by relatively thick peduncles, indicating the use of short burst movements. Further, the mouth and eyes are higher with respect to the size of the head (although this aspect is more related to an ontogenetic process than a feeding one, Stoner and Ottmar 2003). Another important group that we could identify is that of pelagic fish (present in the upper positive zone from the generalist species), which have thin peduncles, as they are more compact for constant movements. Additionally, the origin of their mouths is in the lower part of the head and far towards the back of the body, allowing the greater opening of the jaw and also generating more suction to capture prey (Webb 1984). From the upper positive part of the PCoA to the lower negative area (axis 2 ), we could mainly differentiate a change in locomotion strategies from pelagic species that can be characterized by a continuous, sustained swimming speed to those with less locomotion capacity (Sambilay 1990).

The sites in the GC showed lower functional redundancy than NAY. Consequently, the values of the functional indices were higher in northwest locations because of the diversification of traits (Fig. 3). Similar results had been found by other authors, where localities at higher latitudes presented a higher functional diversity of traits than localities closer to the equator (Stuart-Smith et al. 2013, Toussaint et al. 2016). Considering the geographical proximity of our localities, we corroborated what has been proposed by other authors, which is that these functional indices allow for more sensitive detection of small disturbances (Villéger et al. 2017). Therefore, climáticas y ambientales, lo cual propicia que las señales anuales e interanuales afecten más la entrada de especies de peces al golfo (Escalante et al. 2013). En consecuencia, es común encontrar especies con afinidades tropicales y templadas (González-Acosta et al. 2005).

Por su parte, al comparar la riqueza total de los sitios en el GC contra NAY (111 spp.), se encontró una riqueza de especies reducida en el noroeste de México. Por ejemplo, en NAY fue común la presencia de especies marinas y salobres de las familias Centropomidae, Eleotridae y Sciaenidae, así como algunas especies eurihalinas de agua dulce como aquellas de la familia Cichlidae. En el caso de peces demersales marinos algunas especies de Haemuidae (Anisotremus interruptus y Genyatremus dovii), Lutjanidae (Lutjanus inermis y Lutjanus jordani) y Carangidae (Carangoides otrynter) no estuvieron presentes para la región del noroeste.

\section{El enfoque funcional}

Los 2 primeros ejes en el espacio funcional de la comunidad de peces de manglar explicaron un alto porcentaje de la varianza total debido a que casi todas las especies pertenecieron a los Perciformes. Los atributos con mayor poder de explicación funcional fueron la posición de la boca y la posición del ojo en el primer eje, ambos relacionados con el proceso de alimentación. Mientras tanto, el aspecto del pedúnculo caudal describió mejor el segundo eje y estuvo relacionado con la locomoción. Resultados similares fueron encontrados por Soares et al. (2013) para comunidades de peces en Brasil. Sin embargo, los resultados de la varianza explicada parecen estar magnificados, por el porcentaje de especies presentes de las familias Lutjanidae, Haemulidae, Sciaenidae, Serranidae y Gerreidae (peces similares en su morfología, de ahora en adelante referidos como generalistas). Esto se ha reportado en otras faunas ícticas que han experimentado eventos de alta radiación pero con pequeñas diferencias significativas en las características morfológicas (Toussaint et al. 2016).

Otras adaptaciones de peces en los resultados mostraron a las especies bentónicas sésiles (lenguados, las especies más alejadas del grupo de especies generalistas) en el primer eje. Estas especies se caracterizan por tener pedúnculos relativamente gruesos, lo que indica el uso de movimientos cortos explosivos. Además, la boca y los ojos son más grandes con respecto al tamaño de la cabeza (aunque este aspecto está más relacionado con un proceso ontogenético que uno de alimentación, Stoner y Ottmar 2003). Otro grupo importante que se puede identificar es el de los peces pelágicos (ubicados en la zona de valores positivos arriba de las especies generalistas), los cuales tienen pedúnculos delgados, ya que son más compactos para movimientos constantes. Adicionalmente, el origen de su boca está en la parte inferior de la cabeza y prolongado hacia la parte posterior del cuerpo, lo que permite una mayor apertura de la mandíbula y también genera más succión para capturar presas (Webb 1984). Desde 
the communities in northwest Mexico had a greater diversity of feeding methods and locomotion traits than those at the other sites, due more to the environmental affinity of the species and oceanic conditions than to the heterogeneity of resources (Shahraki et al. 2014). Consequently, the mangrove fish community's richness was structured by a latitudinal gradient (regardless of how small it was), and the community's functional composition was governed by the hydroclimatic conditions. We identified different traits in relation to seasonality. In the warm season, Payan-Alejo (2012) and this study found predators in arid habitat conditions usually related to migratory swimmers, such as members of the Carangidae and Scombridae families. In both studies, adults enter the environment in order to feed on juveniles of some benthopelagic species (e.g., Mugilidae, Gerreidae); we therefore consider them as opportunistic predators.

In the cold season, all authors have reported fewer organisms. However, flatfishes of different families (e.g., Achiridae and Paralichthydae) are found as the temperature in the BCS sites usually drops down to $10{ }^{\circ} \mathrm{C}$ because of the shallow habitats less than $1.5 \mathrm{~m}$ depth. Most of the species migrate to deeper waters where the temperature is more stable. In this context, the mangrove is available with low competition. Therefore, the flatfish, being a species that prefers cold temperatures, capitalizes on this habitat (Wilber et al. 2013). Thus, we do not differentiate 2 community structures but rather temporal functional traits that appear/rise from temperature-related conditions. Additionally, some studies have reported that the substratum is also an important distribution factor for flatfishes, particularly that sediment size is related to their habitat preference (Spinner et al. 2016). In this context, it is possible that the high richness found in the localities of BCS and SON (Padilla-Serrano et al. 2016) is related to the presence of sediments of different sizes in the mangrove substratum (a mixture of lime and small-grained sand).

\section{Fish species and environment}

From an environmental perspective, fish richness in NAY is separated based on its estuarine conditions, such as greater contribution of freshwater and generally lower temperature. Also, as reported by Henriques et al. (2017), habitat extension is related to a higher diversity of species. On the other hand, the localities in the northwest were divided by the evaporation rate, where SON had significantly higher values that separated it from SIN and BCS. From these results, we are able to suggest that salinity, rather than temperature, is a more influential factor in the redundancy of functional traits for the fish in mangroves, even considering the low contribution of freshwater in the arid zones.

Given the hypersaline characteristic of some of the sites analyzed, most of the species had a strictly marine and marine-estuarine affinity. In addition, the presence of peripheral species such as silversides had been related to a wide salinity range (Veale et al. 2014). On the other hand, most of la parte positiva superior del PCoA hacia el área negativa inferior (eje 2), podemos diferenciar principalmente un cambio en las estrategias de locomoción de las especies pelágicas que pueden caracterizarse por una velocidad de nado continua y sostenida a aquellas con menor capacidad de locomoción (Sambilay 1990).

Los sitios en el GC mostraron menor redundancia funcional que NAY. En consecuencia, los valores de los índices funcionales fueron más altos en las localidades del noroeste debido a la diversificación de los atributos (Fig. 3). Otros autores han encontrado resultados similares, donde las localidades en latitudes más altas presentaron una mayor diversidad funcional de atributos que las localidades más cercanas al ecuador (Stuart-Smith et al. 2013, Toussaint et al. 2016). Considerando la proximidad geográfica de las localidades, se corroboró lo que han propuesto otros autores, en el sentido de que estos índices funcionales permiten la detección más sensible de pequeñas perturbaciones (Villéger et al. 2017). Por lo tanto, las comunidades del noroeste de México tenían una mayor diversidad de métodos de alimentación y atributos de locomoción que las de los otros sitios, debido más a la afinidad ambiental de las especies y las condiciones oceánicas que a la heterogeneidad de los recursos (Shahraki et al. 2014). En consecuencia, la riqueza de la comunidad de peces de manglar se estructuró por un gradiente latitudinal (sin importar cuán pequeño fuera), y la composición funcional de la comunidad estuvo regida por las condiciones hidroclimáticas. Se identificaron diferentes atributos en relación con la estacionalidad. En la temporada cálida, PayanAlejo (2012) y el presente estudio encontraron depredadores en condiciones áridas del hábitat generalmente relacionados con nadadores migratorios, como son los miembros de las familias Carangidae y Scombridae. En ambos estudios se presentaron adultos que ingresaron al medio para alimentarse de los juveniles de algunas especies bentopelágicas (e.g., Mugilidae, Gerreidae); por tanto, los consideramos depredadores oportunistas.

En la temporada fría, todos los autores han reportado menos organismos. Sin embargo, se encontraron lenguados de diferentes familias (e.g., Achiridae y Paralichthydae), ya que la temperatura en los sitios de BCS generalmente baja hasta $10{ }^{\circ} \mathrm{C}$ debido a los hábitats someros de menos de $1.5 \mathrm{~m}$ de profundidad. La mayoría de las especies migra hacia aguas más profundas donde la temperatura es más estable. En este contexto el manglar está disponible con una menor competencia, aspecto que capitalizan los lenguados, ya que son especies con preferencia por temperaturas frías (Wilber et al. 2013). Por lo tanto, no diferenciamos 2 estructuras comunitarias, sino, más bien, atributos funcionales temporales que aparecen/se incrementan a partir de las condiciones relacionadas con la temperatura. Además, algunos estudios han reportado que el sustrato también es un factor de distribución importante para los lenguados, particularmente que el tamaño de los sedimentos se relaciona con la preferencia de hábitat (Spinner et al. 2016). En este contexto, es posible 
the species that had some freshwater affinity were found only in environments with regular freshwater contributions (SIN and NAY), whereas some fish like mojarras and sanddabs were also found in areas with the lowest freshwater input (SON and BCS, Vega-Cendejas and De Santillana 2004). Although the species composition from arid localities within the GC differ almost 50\% from that of NAY, the environmental affinity of the ichthyofauna was dominated mainly by marine species. The absence of some pelagic and freshwater species in the GC may be related to the collection method (seine nets) and to the location of the sampling sites (brackish and coastal sections).

\section{Taxonomic diversity}

In the case of the taxonomic structure of the fish community, we identified significant changes at the order level. In other habitats, similar results have been found at this taxonomic resolution (Mueller et al. 2013), suggesting a highly stable habitat. However, it seems more convenient to consider stability at the family level to generate a probabilistic list of families present in these environments. The most diverse and frequent families in the area are in agreement with those reported by Sheaves (2017) as the most likely families to be found in mangrove habitats. However, according to the arid conditions of the mangroves present in the GC, the degree of importance of the families was different. Particularly, the most frequent families are those with a high tolerance for environmental stress, such as Mugilidae, Gerreidae, and Lutjanidae (Mora and Ospína 2001).

The differences in the taxonomic structure were greater when introducing NAY into the analysis. In the probability funnels, SIN was significantly different from the other locations in the northwest (Fig. 5). However, when comparing the distances that separate the points of SIN and NAY from those for the rest of the localities, SIN behaves as a transitive area. The taxonomic structure of the mangrove fish of the northwest gradually changes with respect to the more tropical localities in a latitudinal gradient, an aspect identified in other regions for which these techniques were used (Henriques et al. 2017). Both localities, SIN and NAY, show an increase in species of the Carangidae, Centropomidae, and Sciaenidae families. Contrasting this, NAY presents a greater number of species with estuarine affinity that are absent from the northern section of the GC, which increases the difference in the taxonomic composition of the arid mangroves with respect to the more southern localities.

Future studies must increase the number of sites covered (particularly sites that currently lack information) and evaluate environmental differences in the assembly process of the fish community. This will aid in understanding whether it is the latitudinal position that governs these functional and taxonomic changes or if it is the suboptimal characteristics of the environment that force a higher rate of diversification of species traits (Villéger et al. 2017). que la alta riqueza encontrada en las localidades de BCS y SON (Padilla-Serrano et al. 2016) esté relacionada con la presencia de diferentes tamaños de sedimentos en el sustrato de manglar (una mezcla de limo y arena de grano fino).

\section{Especies de peces y medio ambiente}

En una perspectiva ambiental, la riqueza de peces en NAY se separa con base en su condición estuarina, dados un mayor aporte de agua dulce y la temperatura global más baja. Además, como lo describen Henriques et al. (2017), la extensión del hábitat está relacionada con una mayor diversidad de especies. Por otro lado, las localidades del noroeste están divididas por la tasa de evaporación, donde SON presentó valores significativamente más altos que lo separan de SIN y BCS. A partir de estos resultados, se puede proponer que la salinidad, más que la temperatura, es el factor que más influye en la redundancia de atributos funcionales para los peces en los manglares, aun considerando el bajo aporte de agua dulce en las zonas áridas.

Debido a la característica hipersalina de algunos de los sitios analizados, la mayoría de las especies tuvieron una afinidad estrictamente marina y estuarino-marina. Además, la presencia de especies periféricas como los charales ha sido relacionada con un amplio intervalo de salinidad (Veale et al. 2014). Por otro lado, la mayoría de las especies que tuvieron alguna afinidad dulceacuícola se encontraron solo en ambientes con contribuciones regulares de agua dulce (SIN y NAY), mientras que otros peces como las mojarras y lenguados también se encontraron en áreas con un menor aporte de agua dulce (SON y BCS; Vega-Cendejas y De Santillana 2004). Aunque la composición de especies de las localidades áridas del GC difiere casi en un $50 \%$ de la de NAY, la afinidad ambiental de la ictiofauna estuvo dominada principalmente por especies marinas. La ausencia de algunas especies pelágicas y dulceacuícolas en el GC puede estar relacionada con el método de colecta (redes de cerco), así como con la ubicación de los sitios de muestreo (secciones salobres y costeras).

\section{Diversidad taxonómica}

En el caso de la estructura taxonómica de la comunidad de peces, se identificaron cambios significativos a nivel de orden. En otros hábitats, se han encontrado resultados similares a esta resolución taxonómica (Mueller et al. 2013), lo que sugiere un hábitat altamente estable. Sin embargo, parece más conveniente considerar la estabilidad a nivel de familia para generar una lista de familias que probablemente estén presentes en estos ambientes. Las familias más diversas y frecuentes de la zona coinciden con las reportadas por Sheaves (2017) como aquellas con mayor probabilidad de encontrarse en hábitats de manglar. Sin embargo, de acuerdo con las condiciones áridas de los manglares presentes en el $\mathrm{GC}$, el grado de importancia de las familias fue diferente. 


\section{ACKNOWLEDGMENTS}

JAPA is a fellow graduate student of BEIFI (IPN) and the National Council of Science and Technology (Mexico). RME and GDLCA are Instituto Politécnico Nacional COFAA and EDI fellows.

\section{REFERENCES}

Al-Maslamani I, Walton MEM, Kennedy HA, Al-Mohannadi M, Le Vay L. 2013. Are mangroves in arid environments isolated systems? Life-history and evidence of dietary contribution from inwelling in a mangrove-resident shrimp species. Estuar Coast Shelf Sci. 124:56-63. https://doi.org/10.1016/j.ecss.2013.03.007

Álvarez-Romero JG, Pressey RL, Ban NC, Torre-Cosío J, AburtoOropeza O. 2013. Marine conservation planning in practice: lessons learned from the Gulf of California. Aquat Conserv. 23(4):483-505. https://doi.org/10.1002/aqc.2334

Bady P, Dolédec S, Fesl C, Gayraud S, Bacchi M, Schöll F. 2005. Use of invertebrate traits for the biomonitoring of European large rivers: The effects of sampling effort on genus richness and functional diversity. Freshw Biol. 50(1):159-173. https://doi.org/10.1111/j.1365-2427.2004.01287.x

Barbier EB, Hacker SD, Kennedy C, Koch EW, Stier AC, Silliman BR. 2011. The value of estuarine and coastal ecosystem services. Ecol Monogr. 81(2):169-193. https://doi.org/10.1890/10-1510.1

Bello F, Lepš J, Lavorel S, Moretti M. 2007. Importance of species abundance for assessment of trait composition: an example based on pollinator communities. Commun Ecol. 8(2):163-170. https://doi.org/10.1556/ComEc.8.2007.2.3

Brusca RC, Findley LT, Hastings PA, Hendrickx ME, Torre Cosio J, van der Heiden AM. Macrofaunal diversity in the Gulf of California. 2005. In: Cartron JL, Caballos EG, Felger RS (eds.), Biodiversity, Ecosystems and Conservation in Northern Mexico. Oxford: Oxford University Press. p. 179-203.

Buisson L, Grenouillet G, Villéger S, Canal J, Laffaille P. 2012. Toward a loss of functional diversity in stream fish assemblages under climate change. Glob Chang Biol. 19(2):387-400. https://doi.org/10.1111/gcb.12056

Castro-Aguirre JL, Espinosa-Pérez H, Schmitter-Soto J. 1999. Ictiofauna estuarino-lagunar y vicaria de México. Mexico City: Editorial Limusa. 711 p.

Clarke KR. 1993. Non-parametric multivariate analyses of changes in community structure. Austral Ecol. 18(1):117-143. https://doi.org/10.1111/j.1442-9993.1993.tb00438.x

Clarke KR, Gorley RN. 2006. PRIMER v6: User Manual/Tutorial (Plymouth Routines in Multivariate Ecological Research). Plymouth: PRIMER-E.

Clarke KR, Warwick RM. 1999. The taxonomic distinctness measure of biodiversity: weighting of step lengths between hierarchical levels. Mar Ecol Prog Ser. 184:21-29. https://www.jstor.org/stable/24853226

[CONABIO] Comisión Nacional para el Conocimiento y Uso de la Biodiversidad (MX). 2009. Manglares de México: Extensión y distribución. 2nd ed. Mexico: CONABIO. 128 p.

[CONABIO] Comisión Nacional para el Conocimiento y Uso de la Biodiversidad (MX). 2013. Manglares de México: Extensión, Distribución y Monitoreo. Mexico City: Comisión Nacional para el Conocimiento y Uso de la Biodiversidad. 128 p.
En particular, las familias más frecuentes son aquellas con una alta tolerancia al estrés ambiental, como Mugilidae, Gerreidae y Lutjanidae (Mora y Ospína 2001).

Las diferencias en la estructura taxonómica incrementaron al introducir a NAY en el análisis. En los túneles de probabilidad, SIN fue significativamente diferente de las otras localidades del noroeste (Fig. 5). Sin embargo, al comparar las distancias que separan los puntos de SIN y NAY de los del resto de las localidades, SIN se comporta como un área de transición. La estructura taxonómica de los peces de manglar del noroeste cambia gradualmente con respecto a las localidades más tropicales en un gradiente latitudinal, aspecto identificado en otras regiones para las cuales se utilizaron estas técnicas (Henriques et al. 2017). Ambas localidades, SIN y NAY, muestran un aumento en las especies de las familias Carangidae, Centropomidae y Sciaenidae. Contrariamente, NAY presenta un mayor número de especies con afinidad estuarina que están ausentes en la sección norte del GC, lo cual aumenta la diferencia en la composición taxonómica de los manglares áridos con respecto a las localidades más sureñas.

Los estudios futuros deben aumentar el número de sitios (particularmente sitios que actualmente carezcan de información) y evaluar las diferencias ambientales en el proceso de agrupación de la comunidad de peces. Esto ayudará a identificar si la posición latitudinal es la que dirige los cambios funcionales y taxonómicos o si son las características subóptimas del ambiente las que fomentan una mayor tasa de diversificación de atributos de las especies (Villéger et al. 2017).

\section{Agradecimientos}

JAPA es becario BEIFI (IPN) y del Consejo Nacional de Ciencia y Tecnología (CONACYT). RME y GDLCA son becarios de COFAA y EDI del Instituto Politécnico Nacional.

Costanza R, d'Arge R, Groot R, de Farber S, Grasso M, Hannon B. 1997. The value of the world's ecosystem services and natural capital. Nature. 387:253-260. https://doi.org/10.1038/387253a0

Debastiani VJ, Pillar VD. 2012. SyNCSA-R tool for analysis of metacommunities based on functional traits and phylogeny of the community components. Bioinformatics. 28(15):20672068. https://doi.org/10.1093/bioinformatics/bts325

Escalante F, Valdez-Holguín JE, Álvarez-Borrego S, Lara-Lara JR. 2013. Variación temporal y espacial de temperatura superficial del mar, clorofila $a$ y productividad primaria en el golfo de California $=$ Temporal and spatial variation of sea surface temperature, chlorophyll $a$, and primary productivity in the Gulf of California. Cienc Mar. 39(2):203-215. https://doi.org/10.7773/cm.v39i2.2233

Faunce CH, Serafy JE. 2006. Mangroves as fish habitat: 50 years of field studies. Mar Ecol Prog Ser. 318:1-18.

https://doi.org/10.3354/meps318001 
Payan-Alcacio et al.: Fish functional diversity in arid mangroves

Félix-Pico EF, Holguin-Quiñones OE, Escamilla-Montes R. 2011. Macroinvertebrados marinos asociados al manglar. In: FelixPico EF, Serviere-Zaragoza E, Riosmena-Rodriguez R, LeónDe La Cruz JL (eds.), Los Manglares de la Península de Baja California. La Paz (Baja California Sur, Mexico): Centro Interdisciplinario de Ciencias Marinas, Centro de Investigaciones Biológicas del Noroeste, Universidad Autónoma de Baja California Sur. 326 p.

González-Acosta AF, de la Cruz-Agüero G, de la Cruz-Agüero J, Ruíz-Campos G. 2005. Seasonal pattern of the fish assemblage of El Conchalito mangrove swamp, La Paz Bay, Baja California Sur, Mexico. Hidrobiológica. 15(2):205-214.

Henriques S, Guilhaumon F, Villéger S, Amoroso S, França S, Pasquaud S, Cabral HN, Vasconcelos RP. 2017. Biogeographical region and environmental conditions drive functional traits of estuarine fish assemblages worldwide. Fish Fish. 18(4):752771. https://doi.org/10.1111/faf.12203

Houseman G, Gross KL. 2011. Linking grassland plant diversity to species pools, sorting and plant traits. J Ecol. 99(2):464-472. https://doi.org/10.1111/j.1365-2745.2010.01786.x

Laliberté E, Legendre P. 2010. A distance-based framework for measuring functional diversity from multiple traits. Ecology. 91(1):299-305. https://doi.org/10.1890/08-2244.1

López-Medellín X, Ezcurra E. 2012. The productivity of mangroves in northwestern Mexico: a meta-analysis of current data. J Coast Conserv. 16(3):399-403. https://doi.org/10.1007/s11852-012-0210-7

Lugendo BR, Nagelkerken I, Kruitwagen G, van der Velde G, Mgaya YD. 2007. Relative importance of mangroves as feeding habitats for fishes: A comparison between mangrove habitats with different settings. Bull Mar Sci. 80(3):497-512.

Mason NWH, Mouillot D, Lee WG, Wilson JB. 2005. Functional richness, functional evenness and functional divergence: the primary components of functional diversity. Oikos. 111(1):112-118. https://doi.org/10.1111/j.0030-1299.2005.13886.x

Millán-Aguilar O, Nettel-Hernanz A, Hurtado-Oliva MA, Dodd RS, Flores-Cárdenas F, Manzano-Sarabia M. 2020. Landscape metrics and conservation status of five mangrove wetlands in the eastern Gulf of California margin. J Coast Res. 36(1):94-102. https://doi.org/10.2112/JCOASTRES-D-18-00060.1

Mora C, Ospína A. 2001. Tolerance to high temperatures and potential impact of sea warming on reef fishes of Gorgona Island (tropical eastern Pacific). Mar Biol. 139(4): 765-769. https://doi.org/10.1007/s002270100626

Mueller M, Pander J, Geist J. 2013. Taxonomic sufficiency in freshwater ecosystems: effects of taxonomic resolution, functional traits, and data transformation. Freshw Sci. 32(3):762-778. https://doi.org/10.1899/12-212.1

Ochoa-Gómez JG, Serviere-Zaragoza E, Lluch-Cota DB, RiveraMonroy VH, Oechel W, Troyo-Diéguez E, Lluch-Cota SE. 2018. Structural complexity and biomass of arid zone mangroves in the southwestern Gulf of California: Key factors that influence fish assemblages. J Coast Res. 34(4):979-986. https://doi.org/10.2112/JCOASTRES-D-16-00220.1

Padilla-Serrato J, López-Martínez J, Rodríguez-Romero J, Acevedo-Cervante A, Galván-Magaña F, Lluch-Cota D. 2017. Changes in fish community structures in a coastal lagoon in the Gulf of California, México. Rev Biol Mar Oceano. 52(3):567-579.
https://doi.org/10.4067/S0718-19572017000300013

Padilla-Serrato J, López Martínez J, Rodríguez-Romero J, LluchCota DB, Galván-Magaña F, Acevedo-Cervantes A. 2016. Composición y aspectos biogeograficos del ensamble de peces de la laguna costera Las Guasimas, Sonora, México. Lat Am J Aquat Res. 44(1):85-98.

https://doi.org/10.3856/vol44-issue1-fulltext-9

Payan-Alcacio JA. 2015. Diversidad funcional de la comunidad de peces en hábitats de manglar en la Bahía de La Paz, BCS México. Mexico: Instituto Politécnico Nacional-Centro Interdisciplinario de Ciencias Marinas. 107 p.

Payan-Alejo J. 2012. Estructura de la captura artesanal de peces en el sistema lagunar Santa María La Reforma, Angostura, Sinaloa, durante 2001-2002 [MSc thesis]. [Mexico City]: Universidad Nacional Autónoma de México.

Ramsar. 2008. Ficha Informativa del complejo Lagunar Bahía Guasimas-Estero Lobos. Mexico: Ramsar. 19 p.

Ricotta C, de Bello F, Moretti M, Caccianiga M, Cerabolini BEL, Pavoine S. 2016. Measuring the functional redundancy of biological communities: a quantitative guide. Methods Ecol Evol. 7(11):1386-1395. https://doi.org/10.1111/2041-210X.12604

RStudio Team. 2019. RStudio: Integrated Development for R. Boston (MA): RStudio, PBC; accessed 2019 Oct 18. http:// www.rstudio.com/

Sambilay VC Jr. 1990. Interrelationships between swimming speed, caudal fin aspect ratio and body length of fishes. Fishbyte. 8(3):16-20.

Shahraki M, Fry B, Krumme U, Rixen T. 2014. Microphytobenthos sustain fish food webs in intertidal arid habitats: a comparison between mangrove-lined and un-vegetated creeks in the Persian Gulf. Estuar Coast Shelf. 149:203-212. https://doi.org/10.1016/j.ecss.2014.08.017

Shahraki M, Saint-Paul U, Krumme U, Fry B. 2016. Fish use of intertidal mangrove creeks at Qeshm Island, Iran. Mar Ecol Prog Ser. 542:153-166. https://doi/10.3354/meps11546

Sheaves M. 2017. How many fish use mangroves? The $75 \%$ rule an ill-defined and poorly validated concept. Fish Fish. 18(4):778-789. https://doi.org/10.1111/faf.12213

Soares BE, Ruffeil TOB, Montag LF de A. 2013. Ecomorphological patterns of the fishes inhabiting the tide pools of the Amazonian Coastal Zone, Brazil. Neotrop Ichthyol. 11(4):845-858. http://dx.doi.org/10.1590/S1679-62252013000400013

Spinner M, Kortmann M, Traini C, Gorb SN. 2016. Key role of scale morphology in flatfishes (Pleuronectiformes) in the ability to keep sand. Sci Rep. 6(1):26308. https://doi.org/10.1038/srep26308

Stoner AW, Ottmar ML. 2003. Relationships between size-specific sediment preferences and burial capabilities in juveniles of two Alaska flatfishes. J Exp Mar Biol Ecol. 282(1-2):85-101. https://doi.org/10.1016/S0022-0981(02)00447-1

Stuart-Smith RD, Bates AE, Lefcheck JS, Duffy JE, Baker SC, Thomson RJ, Stuart-Smith JF, Hill NA, Kininmonth SJ, Airoldi L, et al. 2013. Integrating abundance and functional traits reveals new global hotspots of fish diversity. Nature. 501:539-542. https://doi.org/10.1038/nature12529

Toussaint A, Charpin N, Brosse S, Villéger S. 2016. Global functional diversity of freshwater fish is concentrated in the Neotropics while functional vulnerability is widespread. Sci Rep. 6(1):22125.

https://doi.org/10.1038/srep22125 
Vázquez-Botello A. 2011. Vulnerabilidad de las zonas costeras del Pacífico Mexicano (Sinaloa-Nayarit) ante el cambio climático: Primer informe de Proyecto. Mexico: Universidad Nacional Autónoma de México. 99 p.

Veale L, Tweedley JR, Clarke KR, Hallett CS, Potter IC. 2014. Characteristics of the ichthyofauna of a temperate microtidal estuary with a reverse salinity gradient, including inter-decadal comparisons. J Fish Biol. 85(5):1320-1354. https://doi.org/10.1111/jfb.12467

Vega-Cendejas ME, De Santillana MH. 2004. Fish community structure and dynamics in a coastal hypersaline lagoon: Rio Lagartos, Yucatan, Mexico. Estuarine Coast Shelf Sci. 60(2):285-299.

https://doi.org/10.1016/j.ecss.2004.01.005

Villéger S, Brosse S, Mouchet M, Mouillot D, Vanni MJ. 2017. Functional ecology of fish: current approaches and future challenges. Aquat Sci. 79(4):783-801. https://doi.org/10.1007/s00027-017-0546-z

Villéger S, Miranda JR, Hernández DF, Mouillot D. 2010. Contrasting changes in taxonomic vs. functional diversity of tropical fish communities after habitat degradation. Ecol Appl. 20(6):1512-1522. https://doi.org/10.1890/09-1310.1

Webb PW. 1984. Body form, locomotion and foraging in aquatic vertebrates. Amer Zool. 24(1):107-120. https://doi.org/10.1093/icb/24.1.107

Wilber DH, Davis D, Clarke DG, Alcoba CJ, Gallo J. 2013. Winter flounder (Pseudopleuronectes americanus) estuarine habitat use and the association between spring temperature and subsequent year class strength. Estuar Coast Shelf S. 133:251-259. https://doi.org/10.1016/j.ecss.2013.09.004

Zhang C, Fujiwara M, Pawluk M, Liu H, Cao W, Gao X. 2020. Changes in taxonomic and functional diversity of fish communities after catastrophic habitat alteration caused by construction of Three Gorges Dam. Ecol Evol. 10(12):5829-5839. https://doi.org/10.1002/ece3.6320

Received February 2020, accepted August 2020. 